Araştırma Makalesi - Research Article

\title{
Performansa Dayalı Ödeme Sisteminden Duyulan Memnuniyet Ölçeği (PEDÖS) Geliştirme Çalışması
}

\section{The Performance-Based Pay System Satisfaction Scale (PEDOS) Development Study}

\author{
Niyazi Okan ÇOBAN* \\ (iD) 0000-0003-4835-6762 \\ Metin PIŞKIIN** \\ (iD) 0000-0003-3555-636X \\ Müge ERSOY KART***
(iD 0000-0003-4104-1645 \\ ÖZ
}

$\mathrm{Bu}$ çalışmanın amacı, çalışanların performansa dayalı ödeme sistemine ilişkin tutumlarının geçerli ve güvenilir bir şekilde belirlenebilmesini sağlayacak bir tutum ölçeği geliştirmektir. Ölçek geliştirme sürecinde önce ilgili alanyazın ve mevcut ölçekler incelenerek madde havuzu hazırlanmış ve taslak ölçeğin görünüş ve kapsam geçerliğini belirlemek amacıyla uzman görüşüne sunulmuştur. Uzman görüşü sonrası beş dereceli Likert tipi taslak ölçek oluşturulmuştur. Taslak ölçek çalışmaya katılmayı kabul eden 159 katılımciya uygulanarak elde edilen veriler analiz edilmiştir. Ölçek geliștirme çalışması; madde havuzunun oluşturulması, kapsam geçerliliğinin test edilmesi, görünüş geçerliliğinin sınanması, taslak ölçeğin uygulanması, yap1 geçerliliği (faktör analizi ve madde analizi) ve güvenirlik (cronbach alfa güvenirliği) analizlerinin yapılmasından oluşan aşamalı bir süreçte gerçekleştirilmiştir. Yapılan açımlayıcı faktör analizi sonucunda ölçeğin 21 madde ve iki faktörlü bir yapıdan oluştuğu, alt ölçeklerin güvenirlik katsayılarının ise 0,97 ile 0,89 olduğu belirlenmiștir. Elde edilen bulgular ölçeğin, çalışanların performansa dayalı ödeme sistemine yönelik tutumlarını, geçerli ve güvenilir bir şekilde ölçebileceğini ortaya koymuştur.

Anahtar Sözcükler: Performansa dayalı ödeme, performansa dayalı ödemeden duyulan memnuniyet, geçerlilik analizi, güvenirlik analizi, tutum ölçeği

\begin{abstract}
The aim of this study is to develop a valid and reliable attitude scale that will enable us to determine the employees' attidutes towards the performance-based pay system. For devising the scale, after carrying out the nessecary literature review, an item pool was prepared and presented to experts for evaluation of its face and content validity. After this consultation with the experts, a five-point Likert type draft scale was created. The research was carried out on the data obtained from 159 participants agreed to participate in the study. The scale development study was carried out in a stepwise process consisting of creating an item pool, testing the content validity, testing the face validity, applying the draft scale, construct validity (factor analysis and item analysis) and reliability (cronbach alpha reliability) analysis. As a result of the explanatory factor analysis performed on the data obtained, it was shown that the scale consists of a two-factor structure with 21 items and reliability coefficients of 0.97 and 0.89 . The findings show that the scale can reveal the employees' attitudes towards the performance-based pay system validly and reliably.
\end{abstract}

Keywords: Performance-based pay, performancebased pay satisfaction, validity analysis, reliability analysis, attitude scale

Önerilen atıf şekli: Çoban, N. O., Pişkin, M. ve Ersoy Kart, M. (2021). Performansa Dayalı Ödeme Sisteminden Duyulan Memnuniyet Ölçeği (PEDÖS) Geliştirme Çalışması. Sosyal Güvenlik Dergisi (Journal of Social Security). 11(1). 195-214

- Geliş Tarihi/Received: 19/04/2021 • Güncelleme Tarihi/Revised: 10/05/2021 • Kabul Tarihi/Accepted: 14/06/2021

* İKY Bilim Uzmanı, Ankara Üniversitesi, İKY ve Kariyer Danışmanlığı ABD, cobanniyaziokan@gmail.com

** Prof. Dr., Ankara Üniversitesi, Rehberlik ve Psikolojik Danışmanlık ABD, mpiskin@ankara.edu.tr

*** Prof. Dr., Ankara Üniversitesi, Çalışma Ekonomisi ve Endüstri İlişkileri Bölümü, ersoy@politics.ankara.edu.tr 


\section{GİRIŞ}

Performansa dayalı ödeme sistemi, hem teorik tartışmaların hem kurumsal uygulamaların merkezinde yer alan, çok boyutlu ve disiplinler arası bir yapıya sahiptir. Günümüz toplumlarının ekonomik örgütlenmesinde önemli bir model olarak karşımıza çıkan sistem, farklı perspektiflerden değerlendirildiğinde, çok bileşenli yapısının sonucu olarak kimi zaman çözümün, kimi zaman sorunun kaynağı olarak ele alınabilmektedir. Performansa dayalı ödeme sisteminin bağlantılı olduğu temel kavram "performans" olmakla birlikte, esas odak noktası "ödeme sistemi" yani "ücretlendirme" ile performans arasındaki ilişkinin doğasıdır. Alanyazın incelendiğinde performans kavramının ne olduğu konusunda pek çok farklı tanımın yapıldığı görülmektedir. Örneğin, Venkatraman and Ramanujam (1986) performansı herhangi bir stratejinin zaman testi olarak olarak ifade ederken, Neely vd. (1995) performansı amaca yönelik eylemin etkinliği ve verimliliği olarak, Dwight (1999) bir hedefe ulaşılan düzey olarak, Daft (2007) örgütün belirlenen hedeflerine kaynaklarını en etkin biçimde kullanarak ulaşması, Cascio (2008) ise çalışanın görevlerini başarı ile icra etmesi olarak tanımlamaktadırlar. Başka tanımlarda da benzer ifadelere rastlamak mümkündür. Örneğin Bingöl (2006) performansı, bir işin bir çalışan tarafından belirli bir zaman kesiti içinde ve belirlenen koşullara göre yerine getirilme düzeyi olarak tanımlarken, Uysal (2015) "performans kavramını belirli bir süre içinde, bir bireyin ya da bir grubun, bir işi yaparken gösterdiği çabanın ve eylemin, nicel veya nitel sonuçları" olarak nitelemiştir. Tüm çalışanların örgüte sunduğu bireysel katkıların bütünü ise "örgüt performansı" olarak betimlenmektedir. Yukarıdaki tanımlar incelendiğinde "çalışanların iş örgütüne yaptığı katkı" ifadesinin hemen hemen tüm tanımlarda ortak bir husus olduğu dikkati çekmektedir.

Performansa dayalı ödeme sistemi ise performans düzeyi ile ücret düzeyi arasında ilişki kurmaktadır. Performansa dayalı ödeme sistemi, günümüzde uygulanmakta olan ücret sistemlerinden biri olup ödeme sisteminin yani ücretlendirmenin bu temel kavram bağlamında şekillenmesidir. Örgütler, insan kaynakları politikalarıyla da paralel olarak, yapısal özelliklerine uygun farklı ücretlendirme sistemleri (kıdeme dayalı ücret sistemi, performansa dayalı ücret sistemi, beceriye dayalı ücret sistemi, ekibe dayalı ücret sistemi, özendirici ücret sistemi) uygulayabilmektedirler (Sabuncuoğlu, 2013). O halde, bu sistem çalışanların ücretlerinin, yapılan işe ilişkin oluşturulan hedeflere bağlı olarak ortaya çıkan performans doğrultusunda "farklılaştırılması" uygulamasıdır. Performansa dayalı ödemenin altyapısını oluşturan da bu yapıdır (Şendoğdu, 2014).

Performans kavramı kapitalist sistemin bir ürünü gibi görünse de gerçekte bu kavram sadece çağımıza özgü değildir. Performans kavramını zamandan bağımsız olarak emeğin kalitesi ve mükemmele ulaşmak için bir ölçüt gibi düşünmek olasıdır. İnsanoğlu "ben kimim?” veya "neredeyim?" sorularını yanıtlamak ve olan biteni anlamlandırabilmek için olay ve nesneleri değerlendirme eğiliminde olmuştur ki bu belki de "gayriresmî" ilk performans değerlendirmesidir. Üretim sürecinde de bu eğilimin yansımalarının olması kaçınılmazdır. 1900'lü yılların başında üretim sektöründe Taylor'un bilimsel yönetim modelinin hakimiyeti söz konusudur. Bilindiği gibi bu yönetim modelinde "insan" çoğu zaman ikinci plandadır; işin bütününe sahip olmayı engelleyen makinalaşma süreci üretimi artırmıştır, ancak emeği de alınıp satılan bir mala dönüştürmüştür. Taylorist yaklaşımda çalışanlar denetlenir ve "hedef davranışları sergilediklerinde ödüllendirilip, istenilmeyen davranışlar gösterdiklerinde ise cezalandırılırsa" beklenen performansı gösterecekleri varsayılmıştır. Özetle, bu dönemde performansı artırmanın yöntemi iyiyi ödüllendirmek ve kötüyü cezalandırmak olarak görülmüştür (Pink, 2015). 
İnsanın sadece ekonomik ve mekanik bir varlık değil, aynı zamanda sosyal ve psikolojik bir canlı olduğunun kabulü için İnsan İlişkileri Yaklaşımının doğmasına dek beklemek gerekmiştir. Bu yaklaşım, günümüzdeki çağdaş güdüleme ve verimlilik sağlama pratikleri için bir dönüm noktası mahiyetindedir. İnsanın kendisine değer verilmesine dair beklentilerinin karşılanmasının sihirli bir motivasyon ve performans tetikleyicisi olduğunun keşfi, "üçüncü güdü” olarak da isimlendirilen içsel motivasyon kavramının ön plana çıkmasına yol açmıştır. İçsel motivasyon hedonizm odaklı davranışlar için bir hazır oluş halidir ve yapılan işten zevk almanın yanı sıra yeni şeyler öğrenme ve yaratmaya, kendini ve dünyayı geliştirmeye, iyileştirmeye, topluma fayda sağlamaya istekli olmasına da zemin hazırlamaktadır. Zamanla dışsal ödüllerin motivasyonu ve performansı kısmen pekiştirebileceği ve hatta bazen olumsuz etkiler yaratabileceği de fark edilmiş̧tir (Ariely, 2008; Ariely vd., 2009a; Ariely vd., 2009b; Deci, 1970; Gneezy ve Rustichini, 2000; Harlow vd., 1950; Lazear, 2000; Lepper, Greene ve Nisbett, 1973; Kohn, 1993; Mellström ve Johannesson, 2008; Pink, 2010).

Anılan dönüşüm 1980'ler ve 1990'lı yılların başlarında örgütlerde performans ölçme, sorumluluk alma, kaynakları etkili ve verimli kullanma, öncelikleri ve hedefleri belirleme konularında önemli gelişmeler yaşanmasına ve elbette yeni yönetim anlayışlarına yönelmeye sebep olmuştur (Çevik vd., 2008). Sürece eşlik eden örgüt yapısı ve teknolojideki değişimler, kaçınılmaz biçimde "performans" kavramını da "performans değerlendirme yöntemlerini" de değişikliğe uğratmıştır. Özellikle de "başarı" olarak betimlenen nihai çıtının ne olduğu ve nesnel olarak nasıl ölçülebileceği üzerine kuramsal açılımların hatırı sayılır oranda artması ve uygulamaya yansıması adeta bir dönüm noktası olmuştur. Hedeflerin önceliklendiği yönetim sistemleri gibi çağdaş uygulamalar yaygınlık kazanmaya başladıkça, örgütler beşeri sermayelerinin gücüne daha yakından tanıklık etmeye başlamış; öznellikten arınmış rasyonel performans ölçütlerine dayalı performans değerlendirme sistemleri hem çalışanı hem de sermayedarı memnun etmeye başlamıştır. Artan rekabet, hizmet sektöründe yoğunlaşma, sendikaların güç kaybetmesi ve teknolojik ilerlemeler ister kamu kurumu olsun ister özel sektörde faaliyet göstersin her iş örgütünü kaliteli hizmet ve ürün sunarak pazarda tutunmak için çalışanların motivasyonunun güçlü olması gerektiği gerçeğiyle yüzleştirmiştir. 21.yüzyılda bu güdülenmenin ancak insan onuruna yaraşır iş ve adil ücret politikaları aracılığılyla sağlanabileceği ifade edilmektedir. O nedenle de tüm personel için objektif ölçütlere dayanan adil ve şeffaf bir performans değerlendirme modeli oluşturmak artık örgütler için oldukça önemli hale gelmiştir.

Birçok örgüt performans değerlendirme sistemini terfi ve ödüller, ücret-maaş yönetimi, gelişim ve eğitim, atamalar, danışmanlık ve geri besleme gibi farklı amaçlar için kullanmaktadır. $\mathrm{Bu}$ değerlendirmelerin yapılmasının iki temel amacı bulunmaktadır. Amaçlardan ilki ve belki de en önemlisi çalışanların iş performansı düzeyi hakkında bilgi edinmektir. Bu bilgi yönetsel kararlar aşamasında (ücret artışları, ikramiyeler, eğitim, disiplin, terfi vb.) son derece önemli bir veridir. İkinci amaç ise iş tanımında ve başarı için saptanan standartlara ne ölçüde yaklaştıklarına ilişkin çalışanlara geri bildirim vermektir (Boduroğlu, 2013).

Örgütlerde bir bakıma bireylere benzemektedir. Her birini diğerinden farklı kılan özgün ve üstelik görünmeyen bir "ruhu" vardır. Bir örgütü var eden bu ruh, o örgütü oluşturan çalışanlar, çalışma ortamı, çalışılan bina, ortaya çıkan ürün ve ayrıca örgüt kültürü, örgüte aidiyet seviyesi, örgütsel adalet algısı gibi pek çok unsurun bileşeminden ibarettir. Bu durum, bir örgüte uygulanacak performans değerlendirme yönteminin seçiminde, önce o örgütün söz konusu yaşamsal parametrelerinin gözden geçirilmesini, ardından denenmiş ve başarılı sonuçlar vermiş yöntemlerin anılan örgütün dokusuna uyarlanmasını gerektirmektedir. 
Ancak, çalışanların iş performansını ölçmek için geçmişten günümüze değin en çok başvurulan memnuniyet ve/veya motivasyon unsurları çoğunlukla "finansal odaklı, harici ödüller" olmuştur. Nitekim Lepper, Greene ve Nisbett (1973), Kohn (1993), Mellström ve Johannesson (2008), Ariely vd. (2009b) de sürece hakim olan yaklaşımın "şartlı ödüller" olduğunu, çalışanların motivasyonunu artırmak ve onları memnun etmek için genellikle performansa dayalı ücretlendirme ya da "ek ücret ödeme" gibi harici ödüllerin kullanıldığını belirtmektedirler.

Örgütler bir taraftan stratejik hedeflerine ulaşabilmek için performans iyileşmesini ücret artışı ile ödüllendirmeyi planlamakta, diğer taraftan çalışanlarını bu stratejik hedeflere erişme yönünde motive etmektedirler. Ayrıca bu denklemde, çalışan memnuniyeti değişkenine de önemli oranda ağırlık vermekten geri durmamaktadırlar. Kuşkusuz "para", doğası gereği, hangi örgüt ve iş kolu olursa olsun, çalışanlar için güçlü bir motivasyon ve memnuniyet aracıdır. Ancak bulgular çalışanların örgüte bağlılıklarının artması için ücret sisteminin adil olması gereğine işaret etmektedir. Nitekim Keleş (2006) tarafından gerçekleştirilen bir araştırmada, çalışanların örgüt içinde uygulanmakta olan ücret sisteminin adil olduğunu düşündüklerinde, örgütsel bağlılıklarının da olumlu yönde etkilendiği belirlenmiştir. Benzer şekilde Penley ve Gould (1988) örgütüne bağlılık duyan çalışanların kendilerini örgüte adayacaklarını ve yüksek performans sergileyeceklerini, aynı şekilde Allen ve Meyer (1990) örgütüyle özdeşleşen ve örgütüne duygusal bağlılığı olan çalışanların diğerlerine kıyasla daha yüksek performans göstereceklerini ileri sürmektedir. Becker vd. (1996) de "performansın örgütsel bağlılığın bir sonucu” olduğunu öne sürerek çalışanların örgüte güçlü bir şekilde bağlandıklarında işlerini kaybetmemek için uygulanan performansa dayalı ücretlendirme sistemi doğrultusunda daha fazla ücret alabilmek için yüksek performans gösterebileceklerini savunmuştur. Muogbo (2013), özellikle dışsal motivasyonun çalışanlar üzerinde etkili olduğunu görmüş ve ücret konusunda adaletli davranıldığında çalışanların buna yüksek performans gösterme eğilimi ile tepki vereceklerini ileri sürmüştür.

Yapılan diğer çalışmalar da performansa dayalı ödeme sisteminin çalışanların motivasyonunu artırmada etkili bir araç olduğunu, performansa dayalı ödeme sisteminin uygulamaya başlanması ile birlikte örgütlerde yüzde 1 ile yüzde 35 oranında verimlilik artışı sağlanabileceğini ortaya koymuştur (Sabuncuoğlu, 2013). Kalay (2016) sosyal mübadele teorisi bağlamında, örgütteki etkileşim adaletinin neticesi olarak çalışanların performansının yöneticileri ile olan ilişkilerine göre olumlu ya da olumsuz yönde etkilendiğini belirtmiştir. Bunların bir sonucu olarak da günümüzde halihazırda kullanılan (bireysel) performansa dayalı sistemlerine Bedeaux ücret sistemi, Halsey ücret sistemi, Grantt ücret sistemi, Rowan ücret sistemi, Emerson ücret sistemi, Taylor ücret sistemi, doğrusal parça başı, standart saat ya da komisyona dayalı ücret sistemi örnek gösterilebilir (Akçakanat ve Çarıkçı, 2019).

O halde performansa dayalı ödeme sistemleri ile çalışanların bu sistemlere ilişkin memnuniyet düzeyleri nihai performansın oldukça güçlü yordayıcıları olarak değerlendirilebilir. Aynı zamanda, performansa dayalı ödeme sistemi sayesinde yüksek ve düşük performanslı çalışanların fark edilmesinin mümkün olması da işletme yönetimi için yaşamsal bir konu olarak karşımıza çıkmaktadır.

Alanyazın incelendiğinde, örgütlerde uygulanmakta olan performans değerlendirme ya da performansa dayalı ücret sistemlerinin işleyişi ve uygulanmasında "performans değerlendirmesine ilişkin sorunlar, ücret-maaş bütçesinin sınırlı oluşu, çalışanlar arasında işbirliği sorunları, maliyetlerin artması, performans ile ödüllerin ilişkilendirilmesindeki 
zorluklar, sistemin adil işlediğine duyulan güven" gibi birtakım güçlüklerin meydana geldiği ifade edilmektedir (Akçakanat ve Çarıkçı, 2019; Göksel, 2013; Sabuncuoğlu, 2013; Sağbaş vd. 2011; Uyargil, 2008; Uyargil, 2013). Ancak çalışanların performansa dayalı ücret sistemlerine ilişkin algılarının etkisi, henüz ölçülmemiş ve o nedenle de bakir kalmış bir alan olarak görünmektedir. Diğer bir ifadeyle, çalışanların kök ücretin dışında ilave ödemeler getiren söz konusu sistemleri nasıl değerlendirdiklerine dair bir kavrayışa ihtiyaç olduğu düşünülmektedir. $\mathrm{Bu}$ noktada, yapılacak yeni çalışmalarda, performansa dayalı ücret sistemlerinde çalışanların yaşadıkları olumsuzlukların nedenlerine ve çözümlerine odaklanmaya duyulan ihtiyaç, konunun farklı boyutlarına ilişkin objektif "ölçme araçlarına" duyulan ihtiyacı da beraberinde getirmektedir. Çalışanların performansa dayalı ödeme sisteminden duydukları memnuniyetin belirlenmesine ilişkin "bir ölçme aracının" hem alanda yapılacak pek çok çalışmada farklı dinamiklerin analizine katkı sağlayacağı hem de alanda yapılacak yeni çalışmalar için ilham kaynağı olacağı açıktır.

$\mathrm{Bu}$ araştırmada, geçmişten günümüze varlığını sürdürmekte olan ve günümüz ekonomi sisteminde daha da belirgin hale gelen çalışanların performansa dayalı ödeme sisteminden duydukları memnuniyet düzeyini belirlemeyi sağlayacak bir ölçme aracı geliştirmek amaçlanmıştır. Ölçek geliştirme çalışmaları uzun soluklu bir süreç olup doğası gereği sağlam bir teknik donanım (istatistik bilgi ve becerisi) ve ölçülecek değişkene ilişkin kuramsal alan bilgisi gerektirmektedir (Güngör, 2016).

Konuyla ilgili alanyazın incelendiğinde, performansa dayalı ödeme sistemlerine ilişkin çalışanların duygu, düşünce, tutum veya değerlendirmelerini belirlemeyi amaçlayan pek çok araştırmanın gerçekleştirildiği, ancak bu çalışmaların çok büyük bir bölümünde geçerlik ve güvenirlik analizleri yapılmış ölçekler yerine, psikometrik özellikleri daha zayıf olan anketlerin kullanıldığı görülmektedir (Akçakanat 2013; Aljumah, 2015; Aydın, 2017; Brasington, 2016; Çakır, 2014; Çelik, 2009; Demir, 2013; Ertekin, 2012; Gazi, 2006; Kesici, 2005; Kılıç, 2012; Koca, 2019; Kolaylı, 2016; Kovan, 2020; Küçük, 2020; Lee, 2011; Marcotte, 2015; Marsh, 2014; Memiş, 2010; Özdemir, 2019; Öztunç, 2017; Taştan, 2017; Timur, 2007; Uzuner, 2014; Van Staveren, 2014; Yüzden, 2013).

Anketlere ek olarak, az sayıda çalışmada ise ölçeklerin kullanıldığı dikkati çekmektedir (Baday, 2016; Bolat, 2012; Çağlar, 2019; Peker, 2013). Ancak ilginç bir biçimde bu çalışmalarda faktör analizi yapılıp, güvenirlik katsayıları belirlenen ölçme araçlarının sıkça anket diye adlandırıldıkları görülmektedir. Bu ölçeklerden Bolat (2012) tarafından yürütülen ve faktör analizi sonucu iki boyutlu olduğu belirlenen ölçekte faktör isimlerinin belirtilmediği, ayrıca bulguların da faktör bazlı değil, tıpkı anketlerde olduğu gibi madde bazlı yapıldığı görülmüştür. Benzer biçimde Peker (2013) tarafından yürütülen çalışmada da faktör analizi sonucu ölçeğin üç boyutlu olduğu belirtilmesine rağmen, bu faktörlerin isimlendirilemediği dile getirilmiş, istatistiksel analizlerin de alt faktöre göre değil ölçekten elde edilen genel puana göre yapıldığı saptanmıştır. Ayrıca bu ölçekte yer alan maddelerin performansa dayalı tutumları belirlemekten ziyade, performansa dayalı ek ödemenin motivasyon üzerindeki etkisini belirlemeye yönelik olduğu görülmüştür. Baday (2016) ise Mercan (2010) tarafından kullanılan ancak güvenirlik ve geçerlik analizi yapılmayan 15 maddelik anketi kullanarak, ölçeğin psikometrik özelliklerini araştırmıştır. Faktör analizi sonucunda ölçeğin 13 maddeden oluşan üç boyutlu faktörel yapısı tespit edilmiştir. Ancak ilginç biçimde 13 maddelik ölçek tezin ekinde 15 madde olarak yer almıştır. Ayrıca ölçekte yargısal ifadeler yerine anket benzeri kapalı uçlu soruların sorulduğu görülmüştür. Son olarak Çağlar (2019), Baday (2016) tarafından kullanılan maddeleri uyarlayarak Performansa 
Dayalı Ücret Sistemi Ölçeği adını verdiği bir ölçek geliştirmiştir. Bu çalışmada aracın faktör analizi sonucunda 2 faktörlü bir yapısının olduğu (Olumlu Boyut=10 madde; Olumsuz Boyut=5 madde) belirlenmiştir. Ancak bu çalışmada da ilginç bir biçimde ölçek yerine anket terimi kullanılmıştır.

Özetlenecek olursa, çalışanların performansa dayalı ödeme sistemlerine ilişkin tutumlarını belirleme çalışmalarında genellikle anketlerin kullanıldığı, az sayıda çalışmada ölçek kullanıldığı, kullanılan ölçeklerin de çoğu kez ölçek geliştirme standartlarını karşılamadığı, ayrıca bu ölçeklerin tamamına yakınında yer alan maddelerin belli bir sektör (örneğin sağlık, finans, eğitim vb.) dikkate alınarak geliştirildiği, dolayısıyla farklı sektörlerde çalışanlara uygun olmadığ

Yukarıda sıralanan nedenlerle, bu çalışmada belli bir sektöre özgü olmayan, performansa dayalı ödeme sistemine ilişkin çalışan tutumlarının "güvenilir ve geçerli" bir şekilde belirlenebilmesini sağlayacak "bir ölçme aracı geliştirmek" amaçlanmıştır.

\section{I- AMAÇ}

$\mathrm{Bu}$ çalışmanın amacı, çalışanların performansa dayalı ödeme sisteminden duydukları memnuniyet düzeylerini ölçen beş dereceli Likert tipi bir ölçek geliştirmektir. Madde havuzunun oluşturulması aşamasında alanyazın taraması yapılarak daha önce performans ödemesine veya performansa dayalı ücretlendirmeye yönelik diğer çalışmalar için geliştirilmiş ya da farklı çalışmalarda uygulanmış olan anketler ve ölçekler incelenmiştir.

Geliştirilen ölçeğin performansa dayalı ödeme sistemi uygulanan örgütlerde, örgüt çalışanlarının bu sisteme karşı duydukları memnuniyet düzeylerinin ortaya çıkarılması konusuna önemli katkılar sağlayacağı düşünülmektedir. Diğer bir ifadeyle, bu çalışmada çalışanların performansa dayalı ödeme sisteminden duydukları memnuniyet düzeylerinin geçerli ve güvenilir bir şekilde ölçülebilmesini sağlayacak "özgün bir tutum ölçeği" geliştirmek amaçlanmıştır.

\section{II- YÖNTEM}

Likert tipi bir ölçek olan Performansa Dayalı Ödeme Sisteminden Duyulan Memnuniyet Ölçeği'nin (PEDÖS) geliştirilmesi için yapılan çalışma, aşamalı bir süreçte gerçekleştirilmiştir. Çalışmada öncelikle madde havuzu oluşturulmuş, kapsam geçerliliği test edilmiş, görünüş geçerliliği sınanmış, taslak ölçek uygulanmış, yapı geçerliliği (faktör analizi ve madde analizi) ve son olarak güvenirlik (cronbach alfa güvenirliği) analizleri yapılmıştır.

\section{A- Madde Havuzunun Oluşturulması}

Ölçeğin madde havuzunun oluşturulması sırasında alanyazın incelemiş; Timur (2007) tarafından geliştirilen "Hastanelerde Çalışan Performansı ile Ücret Arasındaki İlişki Anketi Doktorlara Sorulacak Sorular” konulu anket, Akçakanat (2013) tarafindan geliştirilen "Performans Yönetimi Bağlamında Hekimlerin Performansa Dayalı Ek Ödeme Sistemine Yönelik Tutumları Üzerine Bir Araştırma" konulu ölçek, Marcotte (2015) tarafından geliştirilen "Performans Ödemesi ve Öğretmenlerin Motivasyon Üzerindeki Etkisi” konulu anket ve Aljumah (2015) tarafından geliştirilen "Çalışanların Performansları Üzerinde Performansa Dayalı Ödeme Sisteminin Etkileri” konulu anket çalışmalarından yararlanılmıştır. Yerli ve yabancı literatürün taranması ile mevcut anket ve ölçeklerin incelenmesi sonrasında 45 maddelik bir madde havuzu oluşturulmuştur. 


\section{B- Geçerlilik Analizi}

Bir ölçme aracının geçerliliği, ölçmek üzere hazırlandığı amaca hizmet etme derecesi veya ölçmeye çalıştı̆̆ 1 şeyi ölçebilme düzeyi, bir diğer deyişle, sadece ölçmeye çalıştığı niteliği ölçmeye duyarlı olması ve ölçmeye çalıştığı niteliği diğer niteliklerden ayırt ederek ölçebilmesi olarak tanımlanmaktadır (Seçer, 2017). Özetle, geçerlilik bir ölçme aracının, ölçülmek istenilen özelliği ölçebilmesidir. Bu kapsamda yapılan çalışmalar aşağıda sunulmuştur.

\section{i) Kapsam Geçerliliği (Uzman Görüşlerinin Alınması)}

Kapsam geçerliliği, bir ölçme aracının ölçmek istediği nitelikleri içerme derecesidir. Ölçeği oluşturan maddelerin, ölçülmek istenen davranışı ölçmede nicelik ve nitelik olarak yeterli olup olmadığının göstergesi kapsam geçerliliği ile elde edilir. Bu çalışmada ölçeğin kapsam geçerliliği, kapsam geçerliliğinin test edilmesi için kullanılan metodlardan biri olan uzman görüşüne başvurularak test edilmiştir (Büyüköztürk, 2013).

Ölçekteki her bir madde için "hedeflenen yapıyı ölçmesi, hedef kitleye uygunluğu, anlaşılabilirliği, doğru ifade edilmişs olması" kriterleri açısından akademisyen ve konu uzmanlarından oluşan 16 kişiden görüş alınmıştır. Uzman görüşleri doğrultusunda ölçeğin madde düzeltmeleri ve seçimi yapılmış, 2 uzman öğretim üyesinin nezaretinde madde havuzunda yer alan madde sayıs1 45'ten 32'ye indirilmiştir. Böylece uzman görüşü metodu ile belirlenen 32 madde rasgele sıralanarak taslak ölçek hazır hale getirilmiştir.

\section{ii) Görünüş Geçerliliği}

Bir ölçme aracının görünüş geçerliliği, ölçmek istediği özelliği ölçüyor olmasını temsil eder. Ölçme aracının başlığı ve içeriğinde yer alan maddelerin tutarlı olması, ölçmek istediği özellik ile ilgili görünüyor olması gerekmektedir. Bu bağlamda, uzman görüşleri de göz önünde bulundurularak geliştirilen taslak ölçeğin, başlı̆̆g ile maddelerinin ve içeriğinin tutarlı olduğu görülmüştür.

\section{C) Uygulama Aşaması}

Oluşturulan 32 maddelik taslak ölçek, Türkiye'de farklı şehirlerde yaşayan, farklı sektörlerde (sağlık, eğitim, finans, danışmanlık, güvenlik vb.) çalışan ve ölçeği doldurmayı kabul eden toplam 159 katılımcıya çevrimiçi olarak uygulanmıştır. Ölçekte yer alan maddeler; "kesinlikle katılmıyorum=1" "katılmıyorum=2", "kararsızım=3", "katılıyorum=4" ve “kesinlikle katılıyorum=5” olmak üzere 1' den 5'e doğru puanlanmıştır. Elde edilen verilerin istatistiksel analizi SPSS 21 paket programında gerçekleştirilmiştir.

\section{i) Araştırma Grubu}

PEDÖS Ölçeği’nin geliştirilmesi sürecinde taslak ölçeği 159 katılımcı doldurmuş; ancak 6 katılımcıdan elde edilen veriler eksik olduğu için veri setinden çıkarılmış, 153 katılımcıdan alınan verilerin analize uygun olduğu belirlenerek değerlendirmeye alınmıştır. Katılımcıların seçiminde amaçlı örnekleme yöntemi kullanılmıştır. Araştırma grubunun demografik özellikleri ile ilgili ayrıntılı bilgiler Tablo 1'de sunulmuştur.

Tablo 1'de görüldüğü gibi araştırmaya katılanların \%41,5'i kadın, \%58,5'i ise erkektir. Eğitim düzeylerine göre dağılımda lise mezunu olan katılımcıların oranı $\% 6,3$, ön lisans mezunu olanların oranı $\% 7,5$, lisans mezunu olanların oranı $\% 55,3$, yüksek lisans mezunu olanların oranı \%25,2 ve doktora mezunu olan katılımcıların oranı \%5,7'dir. Çalışılan sektöre göre dağılımda kamuda çalışanların oranı \%51,6, özel sektörde çalışanların oranı ise 
\%48,4'tür. Çalışma düzenine göre dağılımda sabit mesaili çalışanların oranı \%86,2, vardiyalı çalışanların oranı \%13,8'dir. Çalışma biçimine göre dağılımda kadrolu çalışanların oranı \%74,8, sözleşmeli çalışanların oranı \%25,2'dir. İşyeri büyüklüğüne göre dağılımda mikro işletmede ( 10 'dan az çalışan) çalışanların oranı \%9,4; küçük işletmede (10-49 çalışan) çalışanların oranı \%25,2; orta büyüklükte işletmede (50-249 çalışan) çalışanların oranı \% 17,6 ve büyük işletmelerde ( 250 ve üzeri çalışan) çalışanların oranı ise $\% 47,8$ 'dir.

Tablo 1. Çalışma Grubunun Demografik Özellikleri

\begin{tabular}{|c|c|c|c|}
\hline & & $\mathbf{n}$ & $\%$ \\
\hline \multirow[t]{2}{*}{ Cinsiyet } & Kadın & 66 & 41.5 \\
\hline & Erkek & 93 & 58,5 \\
\hline \multirow[t]{5}{*}{ Ĕgitim } & Lise & 10 & 6,3 \\
\hline & Ön Lisans & 12 & 7,5 \\
\hline & Lisans & 88 & 55,3 \\
\hline & Yüksek Lisans & 40 & 25,2 \\
\hline & Doktora & 9 & 5,7 \\
\hline \multirow[t]{2}{*}{ Çalışılan Sektör } & Kamu & 82 & 51,6 \\
\hline & Özel & 77 & 48,4 \\
\hline \multirow[t]{2}{*}{ Çalışma Düzeni } & Sabit Mesai & 137 & 86,2 \\
\hline & Vardiyalı & 22 & 13,8 \\
\hline \multirow[t]{2}{*}{ Çalışma Biçimi } & Kadrolu & 119 & 74,8 \\
\hline & Sözleşmeli & 40 & 25,2 \\
\hline \multirow[t]{4}{*}{ İşyeri Büyüklüğü } & Mikro işletme (10'dan az çalışan) & 15 & 9,4 \\
\hline & Küçük işletme (10-49 çalışan) & 40 & 25,2 \\
\hline & $\begin{array}{l}\text { Orta büyüklükte işletme (50-249 } \\
\text { çalışan) }\end{array}$ & 28 & 17,6 \\
\hline & Büyük işletme (250 ve üzeri çalışan) & 76 & 47,8 \\
\hline
\end{tabular}

\section{ii) Verilerin Toplanması ve Analizi Süreci}

Veri toplama işlemi 13 Ağustos-13 Eylül 2020 tarihleri arasında yürütülmüştür. PEDÖS ölçeğinin performansa dayalı ödeme çalışmalarında yaygın olarak kullanabilir bir ölçek olması amaçlanmıştır. Yaşanmakta olan COVID-19 Pandemisi nedeniyle, çevrimiçi (GoogleForm) olarak hazırlanan ölçek formu sektör ya da kent sınırlaması yapılmaksızın katılımcıların erişimine açılmıştır. GoogleForm üzerinden düzenlenen ölçeğe katılımcıların tamamı çevrimiçi olarak ulaşmıştır. Ölçeğin yönergesinde çalışmanın amacı açıklanmış olup, ayrıca bilgilendirilmiş onam formu yer almıştır. Çalışmaya katılmayı kabul edenler önce 32 maddeden oluşan ölçek formunu, ardından demografik bilgi formunu doldurmuştur.

Çalışmada internet tabanlı çevrimiçi veri toplama yönteminin tercih edilmesi katılımcılara kolay ulaşma imkanı sunmuştur. Ayrıca verilerin aktarılması, hızlı, doğru ve etkili biçimde işlenmesi sürecinde de araştırmacılara zaman ve maliyet bakımından önemli avantajlar sağlamıştır.

\section{D-Bulgular}

\section{i) Yapı Geçerliliği (Faktör Analizi)}

Kapsam geçerliliği ve görünüş geçerliliğinin test edilmesi ve ölçeğin uygulama aşamasının tamamlanmasından sonra taslak ölçekteki 32 maddenin hangilerinin ölçekte yer alacağının belirlenmesi amacıyla faktör analizi yapılarak ölçeğin yapı geçerliliği incelenmiştir. 
Faktör analizi kapsamında ölçme aracını oluşturan maddelerin birbirine benzer nitelikte ve homojen olması beklenmektedir (Seçer, 2017). Bu bağlamda, çalışmada ölçek maddelerinden alınan puanlar ile ölçeğin toplam puanı arasındaki ilişkiyi açıklayan "madde - toplam test korelasyonları” hesaplanarak her bir maddenin ayırt ediciliği ölçülmüştür.

Madde-toplam test korelasyonları yorumlanırken, madde-toplam test korelasyonu 0,30 ve daha yüksek olan maddelerin ölçülen özellik bakımından “iyi derecede” ayırt edici olduğu ifade edilmekte; 0,20-0,30 arasında kalan maddelerin zorunlu görülmesi durumunda ölçeğe alınabileceği veya ölçek maddelerinin düzeltilebileceği; 0,20'den daha düşük maddelerin ise ölçeğe alınmaması gerektiği önerilmektedir (Büyüköztürk, 2013). Yapılan çalışmada da verilere ilişkin madde-test korelasyonları, birinci faktör yükleri ve madde ortalamaları hesaplanmış ve madde test korelasyonunun anlamlı $(\mathrm{p}<0,05)$ olduğu belirlenmiştir.

Bir ölçme aracının geçerliği, aracın ölçmeyi amaçladığı özelliği ne denli doğru ölçtüğüne işaret etmektedir. Bilindiği gibi faktör analizinin yapılabilmesi için yeterli sayıda katılımcıya ulaşılması gerekmektedir. Örneklemin yeterliğini değerlendirmek üzere hesaplanan KaiserMeyer- Olkin (KMO) katsayısının $(0,92)$ istenir düzeyde çıkması ve faktör analizinin geçerliğini sınayan Bartlett testi sonucunun da anlamlı $(4609,112, \mathrm{p}<.000)$ olması nedeniyle faktör analizinin yapılabileceği görülmüştür (Büyüköztürk, 2013).

32 maddelik "PEDÖS” ün yapı geçerliğinin incelenmesi için yapılan Açımlayıcı Faktör Analizi (AFA) işleminde faktörleştirme tekniği olarak Temel Bileşenler Analizi (Principal Components Analysis) yöntemi kullanılmıştır. Ölçeğin kaç faktör içerdiği belirlenirken özdeğeri 1 ve 1 'den büyük faktörler ele alınmış ve faktörlere ilişkin çizgi grafiğine de bakılmıştır. Temel Bileşenler Analizi sonucunda maddelerin ortak varyansı açıklama oranlarının 0,38 ile 0,84 arasında değiştiği görülmüştür. Madde yük değeri 0,50' den küçük olan üç madde (5., 25. ve 26.maddeler) çıkarılmış ve analiz tekrarlanmış; maddelerin ortak varyansı açıklama oranlarının 0,52 ile 0,85 arasında değiştiği görülmüştür.

Bileşenler Matrisi (Component Matrix) incelendiğinde de birbirine yakın yük değerleri olduğu belirlenmiş; faktörlerin birbirleriyle korelasyonlarının anlamlı olabileceği düşünülmüştür. Elde edilen faktörlerin, "bağımsızlık, yorumlamada açıklık ve anlamlılık" açısından belirginleşmesi için eksen döndürmesine tabi tutulması uygun görülmüş, bu amaçla oblik rotasyon uygulanarak "direkt oblimin" tekniği kullanılmıştır. Analiz sonucunda antiimaj korelasyon matrisinde tüm çapraz ilişki katsayılarının 0,50 değerinden büyük olduğu saptanmıştır. Açıklanan toplam varyansa bakıldığında, özdeğeri 1'den büyük olan 3 faktörün ortaya çıktığı görülmüştür. Bu üç faktörün ölçeğe ilişkin açıkladıkları varyans \%69,80'dir. Birinci faktör \% $\% 4,35$, ikinci faktör \% 10,69 ve üçüncü faktör \%4,76 varyans açıklamıştır.

Faktörlerin yorumu için "pattern matrix" incelendiğinde, 23. maddenin üçüncü faktörde tek başına kaldığı; 30. maddenin ise her iki faktörde de birbirine çok yakın yük değerine sahip olduğu görülmüştür. 31. madde ise üç faktörün hiçbirine yerleşmemiştir. Ayırdedicilik bakımından bu üç maddenin çıkarılması uygun görülerek analiz tekrarlanmıştır.

Tekrarlanan analiz sonucunda üç faktörün açıkladığı varyans \%71,1'e yükselmiştir. Pattern matrix incelendiğinde, bu kez 17., 20. ve 24. maddelerin iki faktöre benzer yüklerle yerleştiği tespit edilmiştir. $\mathrm{Bu}$ üç madde de çıkarılarak tekrarlanan analiz sonuçları ölçeğin "iki faktörlü” hale dönüş̧üğünü ortaya çıkarmıştır. Maddelerin ortak varyansı açıklama oranlarının 0,52 ile 0,80 arasında değiştiği görülmüştür. Özdeğeri 1'den büyük iki faktörün 
Sosyal Güvenlik Dergisi • Journal of Social Security • 2021/1

açıkladıkları toplam varyans \%68,34’ dür. Birinci faktör \%55,45, ikinci faktör \%12,89 varyans açıklamaktadır.

23 maddelik ölçeğin döndürülmüş temel bileşenler analizi sonuçları Tablo 2'de yer almaktadır. Madde içerikleri incelendiğinde, birinci faktör için en uygun faktör adının "olumlu tutum”; ikinci faktör için ise "kaygılı tutum” olduğuna karar verilmiştir.

Tablo 2. Döndürülmüş Temel Bileşenler Analizi Sonuçları (Pattern Matrix)

\begin{tabular}{|c|c|c|}
\hline & \multicolumn{2}{|c|}{ Bileșenler } \\
\hline & Olumlu Tutum & Kaygılı Tutum \\
\hline Madde 1 & 0,829 & \\
\hline Madde 2 & 0,820 & \\
\hline Madde 3 & 0,853 & \\
\hline Madde 4 & 0,870 & \\
\hline Madde 6 & 0,800 & \\
\hline Madde 7 & 0,850 & \\
\hline Madde 8 & 0,781 & \\
\hline Madde 9 & 0,745 & \\
\hline Madde 10 & 0,898 & \\
\hline Madde 11 & & 0,834 \\
\hline Madde 12 & & 0,920 \\
\hline Madde 13 & & 0,790 \\
\hline Madde 14 & & 0,624 \\
\hline Madde 15 & 0,898 & \\
\hline Madde 16 & 0,835 & \\
\hline Madde 18 & & 0,622 \\
\hline Madde 19 & 0,855 & \\
\hline Madde 21 & & 0,654 \\
\hline Madde 22 & 0,902 & \\
\hline Madde 27 & & 0,656 \\
\hline Madde 28 & 0,716 & \\
\hline Madde 29 & 0,826 & \\
\hline Madde 32 & 0,638 & \\
\hline
\end{tabular}

Ancak birinci faktörde yer alan 19. ve 32. maddelerin, güvenirlik açısından alfa katsayısını aynen (0.97) kalacak şekilde etkilemediği görülmüştür. O nedenle bu iki madde de çıkarılarak faktör analizi tekrarlanmıştır. Böylece, son hali verilen 21 maddelik ölçeğin, özdeğeri 1'den büyük iki faktörün açıkladıkları toplam varyansı $\% 69,25$ 'e yükselmiştir. Birinci faktör $\% 55,65$, ikinci faktör $\% 13,60$ varyans açıklamaktadır. Ölçeğin döndürülmüş temel bileşenler analizi sonuçları Tablo 3' de yer almaktadır. 
Tablo 3. 21 Maddelik Ölçeğin Son Formunun Direkt Oblimin Döndürme Yöntemine Göre Analiz Sonuçları

Döndürme Sonrası Yük Değerleri

\begin{tabular}{|c|c|c|}
\hline & Olumlu Tutum & Kaygılı Tutum \\
\hline Madde 1 & 0,848 & \\
\hline Madde 2 & 0,839 & \\
\hline Madde 3 & 0,866 & \\
\hline Madde 4 & 0,876 & \\
\hline Madde 6 & 0,808 & \\
\hline Madde 7 & 0,866 & \\
\hline Madde 8 & 0,792 & \\
\hline Madde 9 & 0,755 & \\
\hline Madde 10 & 0,900 & \\
\hline Madde 15 & 0,892 & \\
\hline Madde 16 & 0,827 & \\
\hline Madde 22 & 0,904 & \\
\hline Madde 28 & 0,712 & \\
\hline Madde 29 & 0,826 & \\
\hline Madde 11 & & 0,840 \\
\hline Madde 12 & & 0,919 \\
\hline Madde 13 & & 0,793 \\
\hline Madde 14 & & 0,639 \\
\hline Madde 18 & & 0,620 \\
\hline Madde 21 & & 0,649 \\
\hline Madde 27 & & 0,662 \\
\hline Özdeğerler & 11,687 & 2,855 \\
\hline Varyans Yüzdeleri & 55,65 & 13,60 \\
\hline Açıklanan Toplam Varyans & & \\
\hline Cronbach Alpha Katsayıları & 0,97 & 0,89 \\
\hline
\end{tabular}

\section{ii) Yapı Geçerliliği (Madde Analizi)}

Madde analizi için madde-toplam puan korelasyonlarından yararlanılmıştır. Madde- toplam puan korelasyonlarının "birinci faktör-olumlu tutum" alt ölçeği için 0,79 ile 0,89 ve "ikinci faktör-kaygılı tutum" alt ölçeği için ise 0,73 ile 0,81 arasında değiştiği belirlenmiştir. Tablo 4'de yer alan analiz sonuçlarına göre her bir faktördeki maddeler, o faktörün tümüyle tutarlıdır ve her ilgili madde faktörün ölçtüğü yapıyı ölçmektedir. 
Tablo 4. Madde - Toplam Puan Korelasyonlart

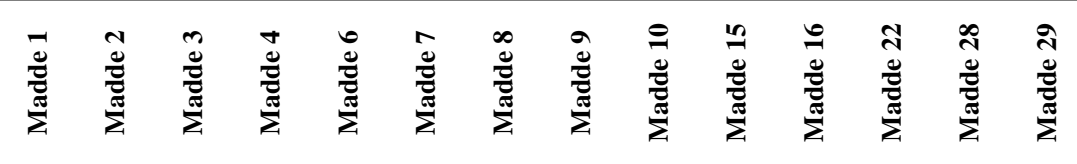

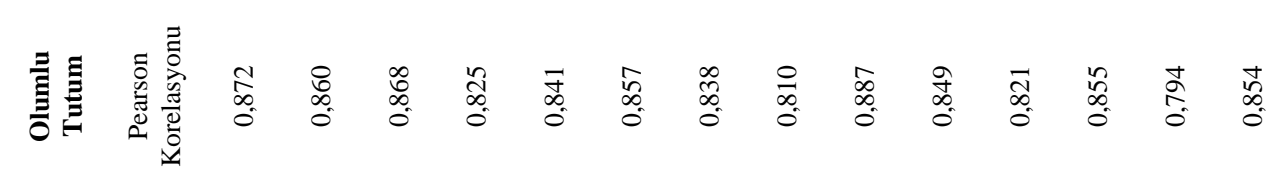

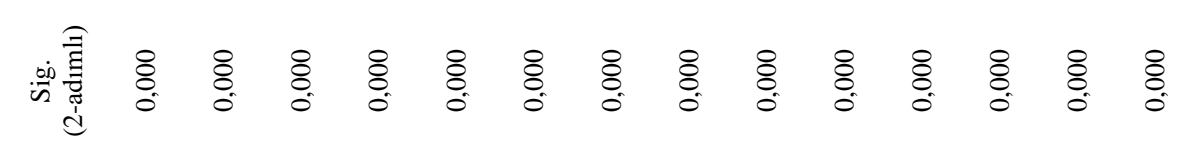

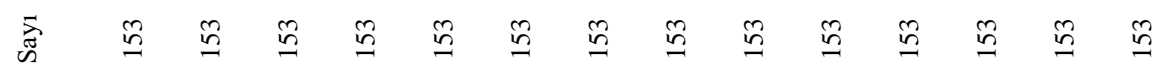

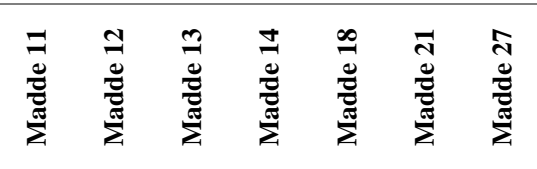

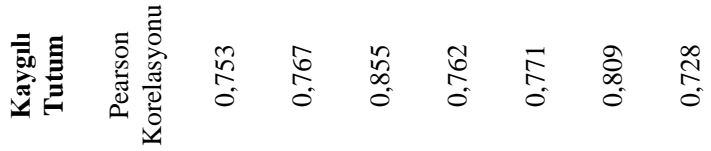

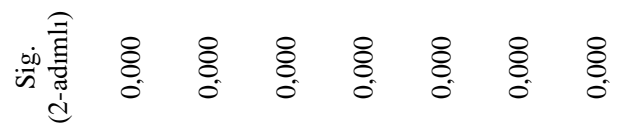

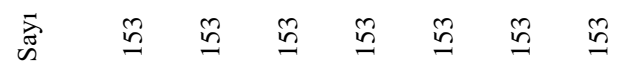

Maddelerin ayırt edicilik gücünü yani ölçeğin iç geçerliğini belirlemek üzere "uç grup" (extreme group) yöntemi kullanılmıştır (Tezbaşaran, 1997). Üst grup her boyuttan en yüksek puan alan katılımcıların \%27'si $(n=41)$, alt grup ise her bir boyuttan en düşük puan alan katılımcıların \%27'si $(n=41)$ olarak belirlenmiştir. Ölçekten alınan puanların uç gruplara ayrılan grupları ne düzeyde ayırabildiğini anlamak amacıyla t-testi analizi yapılmış ve bu analizin sonuçları Tablo 5'de özetlenmiştir.

$\mathrm{Bu}$ testin sonuçlarına göre ölçeğin madde ortalamaları arasında anlamlı farklar görülmüştür. Bu durumda maddelerin PEDÖS bakımından ayırt edici olduğu kararına varılmıştır. Bilindiği gibi \%27'lik gruplar arasında istendik yönde gözlenen farkların anlamlı çıkması, testin iç tutarlılığının bir göstergesi olarak kabul edilmektedir (Büyüköztürk, 2013). 
Tablo 5. T-testi Analizi (Uç Grup Yöntemi) Sonuçları

\begin{tabular}{|c|c|c|c|c|}
\hline Maddeler & $\begin{array}{l}\text { Düzeltilmiş Madde } \\
\text { Toplam } \\
\text { Korelasyonu }\end{array}$ & $\begin{array}{l}\text { Üst \%27 } \\
\text { Ortalaması }\end{array}$ & $\begin{array}{c}\text { Alt } \% 27 \\
\text { Ortalaması }\end{array}$ & $t$ değeri \\
\hline \multicolumn{5}{|c|}{ Birinci Faktör için Alfa $=0,97$} \\
\hline Madde 1 & 0,849 & 2,1707 & 4,2195 & $-8,520$ \\
\hline Madde 2 & 0,836 & 2,2683 & 4,3902 & $-8,969$ \\
\hline Madde 3 & 0,845 & 2,4390 & 4,5122 & $-9,142$ \\
\hline Madde 4 & 0,795 & 2,3902 & 4,3171 & $-8,021$ \\
\hline Madde 6 & 0,814 & 2,2683 & 4,2439 & $-8,098$ \\
\hline Madde 7 & 0,831 & 2,2683 & 4,2439 & $-7,860$ \\
\hline Madde 8 & 0,809 & 1,7561 & 3,6341 & $-8,059$ \\
\hline Madde 9 & 0,778 & 1,8537 & 3,5366 & $-7,055$ \\
\hline Madde 10 & 0,867 & 2,0976 & 4,1463 & $-9,729$ \\
\hline Madde 15 & 0,823 & 2,3415 & 4,2927 & $-8,637$ \\
\hline Madde 16 & 0,791 & 2,3902 & 4,0488 & $-6,867$ \\
\hline Madde 22 & 0,830 & 2,6098 & 4,3415 & $-7,196$ \\
\hline Madde 28 & 0,760 & 2,2683 & 4,1220 & $-7,417$ \\
\hline Madde 29 & 0,827 & 2,2927 & 4,1463 & $-7,375$ \\
\hline \multicolumn{5}{|c|}{ İkinci Faktör için Alfa $=0,89$} \\
\hline Madde 11 & 0,653 & 2,4878 & 4,1951 & $-6,823$ \\
\hline Madde 12 & 0,676 & 2,3659 & 4,4878 & $-9,745$ \\
\hline Madde 13 & 0,790 & 1,9756 & 4,4878 & $-14,215$ \\
\hline Madde 14 & 0,656 & 1,9756 & 4,3415 & $-10,442$ \\
\hline Madde 18 & 0,679 & 1,7073 & 3,8780 & $-10,159$ \\
\hline Madde 21 & 0,730 & 1,6341 & 3,9024 & $-11,947$ \\
\hline Madde 27 & 0,629 & 2,2195 & 4,2195 & $-10,631$ \\
\hline$* \mathrm{p}<.05$ & & & & \\
\hline
\end{tabular}


$\mathrm{Bu}$ testin sonuçlarına göre alt boyutların madde ortalamaları arasında anlamlı farklar görülmüştür. $\mathrm{Bu}$ durumda maddelerin performans ödemesinden memnuniyet eğilimini belirleyen Faktör 1 (Olumlu Tutum) ve Faktör 2 (Kaygılı Tutum) bakımından ayırt edici olduğu kararına varılmıştır. PEDÖS Ölçeği'nin boyutları arasında hesaplanan -0,52 korelasyon değeri de ölçeğin geçerliğini destekler nitelikte bulunmuştur.

\section{iii) Güvenirlik Analizi}

Bir ölçme aracının taşıması gereken diğer bir önemli teknik özellik de güvenilir olmasıdır. Bir ölçme aracında güvenirlik en temel olarak ölçme sonuçlarının kararlılık derecesi olarak ya da ölçme sonuçlarının hatalardan arınık olma derecesi olarak tanımlanmaktadır. Bir ölçme aracının güvenirliğinden bahsederken aynı zamanda ölçme aracının tesadüfi hatalardan arınık olma derecesinden de bahsedilmektedir (Seçer, 2017).

\section{iv) Cronbach Alpha Yöntemi}

Ölçme araçlarında güvenirlik belirleme yöntemlerinden biri olan ve iç tutarlılığın belirlenmesinde sıklıkla başvurulan yöntem olan Cronbach alpha yöntemi, maddelerin birbirleri ile olan uyumuna dayanmaktadır. Amaç ölçekte yer alan maddelerin birbirleriyle uyum düzeylerini ortaya çıkarmaktır. Cronbach alpha katsayısı Likert tipi dereceleme türü ölçeklerde sıklıkla kullanılmaktadır.

Cronbach alpha değerinin ölçek çalışmalarında en az 0,70 ve üzeri olması gerektiği genel kabul görmektedir. Likert tipi bir ölçekte yeterli sayılabilecek güvenirlik katsayısının olabildiğince 1'e yakın olması beklenmektedir (Tezbaşaran, 2008). Murphy ve Davidshofer'e (2005) göre Cronbach alpha değerinin 0,80-0,90 arasında olması durumunda orta düzey güvenirlik, 0,90 üzerinde olması durumunda yüksek güvenirlik ifade ettiği kabul edilmektedir.

$\mathrm{Bu}$ bağlamda geliştirilen ölçeğin iç tutarlılığını incelemek için yapılan faktör analizinde Cronbach alpha katsayısı hesaplanmış, ölçeğin Cronbach alpha iç tutarlılık katsayıları 1.faktör için 0,97, 2.faktör için 0,89 bulunmuştur. Bu katsayıların 1'e çok yakın değerler olmaları ölçeğin güvenilirliğinin yüksek düzeyde olduğunu göstermektedir.

\section{E- Ölçeğin Puanlanması}

Toplam 21 maddeden oluşan ölçeğin 1.-14. maddeleri “olumlu tutumu”, 15.-21. maddeleri ise "kaygılı tutumu” ölçmektedir. Ölçekte tersten puanlama bulunmamakta, ölçekten tek bir toplam puan elde edilmemektedir. Ölçekteki her faktör kendi içinde değerlendirilmekte olup her faktörün kendi toplam puanı vardır. İlk 14 sorudan alınan toplam puan personelin çalıştığı kurumda uygulanan performansa dayalı ödeme sistemine ilişkin olumlu tutumunu göstermektedir. Olumlu tutum puanı ne kadar yüksek olursa çalışanların performansa dayalı ödeme sistemine ilişkin tutumlarının da o kadar olumlu olduğu söylenebilir. Son 7 sorudan alınan toplam puan ise çalışanların performansa dayalı ödeme sistemine ilişkin kaygılı tutumunu göstermektedir. Kaygılı tutum puanı ne kadar yüksek olursa çalışanların performansa dayalı ödeme sistemine ilişkin tutumlarının da o kadar kaygılı ve olumsuz olduğu söylenebilir. 


\section{SONUÇ}

Örgütlerde insan kaynakları yönetiminin stratejik açıdan önem kazanmasıyla birlikte performansa dayalı ücret uygulamalarına daha fazla ilgi duyulmaya başlanmıştır. $\mathrm{Bu}$ uygulamalarda ücretler, performansla ilişkilendirilmektedir. Örgütler hedeflerine ulaşabilmeleri için performansa dayalı ödeme sistemini stratejik bir araç olarak görmektedirler. Ancak mevcut Türkçe literatür incelendiğinde, çalışanların kendi kurumlarında uygulanan performansa dayalı ödeme sistemlerine ilişkin tutumlarını belirlemeyi sağlayan yeterli sayıda ölçeğin olmadığı, var olan ölçeklerin de çoğu kez ölçek geliştirme standartlarını karşılamadığı tespit edilmiştir. Bu nedenle geliştirilen PEDÖS Ölçeğinin performansa dayalı ödeme sistemine ilişkin tutumların güvenilir ve geçerli bir şekilde belirlenebilmesini sağlaması, ve alanyazındaki boşluğu doldurması temenni edilmektedir.

PEDÖS Ölçeği'nin geliştirilmesi için öncelikle madde havuzu oluşturulmuş, kapsam geçerliliği test edilmiş, görünüş geçerliliği sınanmış, taslak ölçek uygulanmış, yapı geçerliliği (faktör analizi ve madde analizi) ve son olarak güvenirlik (cronbach alfa güvenirliği) analizleri yapılmıştır. Bu aşamaların akabinde 21 maddelik PEDÖS ölçeğinin, iki faktörlü yapısı psikometrik olarak kanıtlanmış, ölçeğin toplam varyansının \%69,25'ini açıkladığı görülmüş, ayrıca ölçeğin güvenilirliğinin yüksek olduğu saptanmış; 1.faktör (olumlu tutum) için 0,97, 2.faktör (kaygılı tutum) için 0,89 iç tutarlılık katsayısı hesaplanmıştır.

Analiz sonunda elde edilen bulgular, PEDÖS ölçeğinin çalışanların performansa dayalı ödemeden duydukları memnuniyet düzeylerini ölçebilecek geçerli ve güvenilir bir ölçme aracı olduğunu göstermiştir. Ölçeğin özgün bir tutum ölçeği olması nedeniyle Türkçe alanyazına önemli katkı sağlayacağı umulmaktadır.

\section{Yazarların Notu}

Ek 1'de yer alan "Performansa Dayalı Ödeme Sisteminden Duyulan Memnuniyet Ölçeği" (PEDÖS) araştırmacılar tarafından referans verme koşuluyla bilimsel çalışmalarda kullanılabilir; araştırmacıların ayrıca yazarlardan izin almaları gerekmemektedir.

\section{Kaynakça}

Akçakanat, T. (2013). Üniversite Hastanelerinde Çalışan Öğretim Üyelerinin Performansa Dayall Ek Ödeme Sistemine Yönelik Tutumları Üzerine Bir Araştırma. Doktora Tezi. Süleyman Demirel Üniversitesi Sosyal Bilimler Enstitüsü. Isparta.

Akçakanat, T. ve Çarıç̧ı, İ. H. (2019). Performansa Dayalı Ücret Sistemi ve Sağllk Kurumlarında Uygulanmast. İstanbul: Hiper Yayın.

Aljumah, A. (2015). The Effect of the Performance Related Pay System on the Performance of the Employees in Saudi National Firms: Three Case Studies. PhD. Thesis. University of Wolverhampton. West Midlands.

Allen, N. J. and Meyer, J. P. (1990). The Measurement and Antecedents of Affective. Continuance and Normative Commitment to the Organization. Journal of Occupational Psychology. 63. 1-18.
Ariely, D., Gneezy, U., Lowenstein, G. ve Mazar, N. (2009a). Large Stakes and Big Mistakes. Review of Economic Studies. 76. 451.469.

Ariely, D., Bracha, A. ve Meier, S. (2009b). Doing Good or Doing Well? Image Motivation and Monetary Incentives in Behaving Prosocially. American Economic Review. 99(1). 544-555.

Ariely, D. (November 19. 2008). What's the Value of a Big Bonus?. New York Times. [http://www.nytimes.com/2008/11/20/opinion/2 0ariely.html?_r=0 ]. (Erişim: 2 Mayıs 2020)

Aydın, E. (2017). Sağlı Sektöründe Performansa Dayall Ücretlendirme Sisteminin Değerlendirilmesi (Bursa Devlet Hastanesi ve Ali Osman Sönmez Onkoloji Hastanesi Örneği). Yüksek Lisans Tezi. Atılım Üniversitesi Sosyal Bilimler Enstitüsü. Ankara. 
Baday, M. (2016). Performansa Dayall Ücretlendirme Sisteminin Motivasyona Etkileri Üzerine Dair Bir Alan Çalışması. Yüksek Lisans Tezi. İstanbul Gelişim Üniversitesi Sosyal Bilimler Enstitüsü. İstanbul.

Becker, T., Billings, R., Eveleth, D. ve Gilbert, N. (1996). Foci and Bases of Employee Commitment: Implications for Job Performance. Academy of Management Journal. 39. 464-482.

Bingöl, D. (2006). İnsan Kaynakları Yönetimi. İstanbul: Arıkan Yayınları.

Boduroğlu, N. (2013). Mali Müşavirler Odasinda Performans Değerlendirme Yöntemleri ve Çalışanlar Üzerindeki Etkisi. Yüksek Lisans Tezi. Beykent Üniversitesi Sosyal Bilimler Enstitüsü. İstanbul.

Bolat, G. (2012). Performansa Dayalı Ücret Sisteminin İşgören Motivasyonuna Etkisi. Yüksek Lisans Tezi. Atılım Üniversitesi Sosyal Bilimler Enstitüsü. Ankara.

Brasington, J. A. (2016). School Administrotor Perception of Merit Pay on Motivation and Job Performance: A Descriptive Case Study. PhD. Thesis. University of Michigan, Flint.

Büyüköztürk, Ş. (2013). Sosyal Bilimler için Veri Analizi El Kitabı. Ankara: Pegem Akademi.

Cascio, W. F. (2008). Managing Human Resources: Productivity. Quality of Work Life. Profits (8th Ed.). New York: McGraw-Hill.

Çağlar, Y. (2019). Performansa Dayalı Ücretlendirmenin Çalışan Performansı Üzerindeki Etkileri. Yüksek Lisans Tezi. Beykent Üniversitesi Sosyal Bilimler Enstitüsü. İstanbul.

Çakır, N. (2014). Performansa Dayalı Ek Ödeme Sisteminin Sağlık Çalışanları Açısından Değerlendirilmesi (Sarayköy Devlet Hastanesi Örneği). Yüksek Lisans Tezi. Beykent Üniversitesi Sosyal Bilimler Enstitüsü. İstanbul.

Çelik, G. Ö. (2009). Kamu Çalı̧̧anlarının Performansa Dayalı Ücrete İlişkin Algılamaları. Yüksek Lisans Tezi. Sakarya Üniversitesi Sosyal Bilimler Enstitüsü. Sakarya.

Çevik, H., Göksu, T., Bilgiç, V., Karakaya, M. ve Seyhan, K. (2008). Kamu Kurumlarında Performans Yönetimi. Ankara: Seçkin Yayıncılık.

Daft, R. L. (2007). Management (8th Ed.). Ohio: Thoumson South-Western.
Deci, E. (1971). Effects of Externally Mediated Rewards on Intrinsic Motivation. Journal of Personality and Social Psychology. 18(1).

Demir, R. (2013). Performansla İlişkili Ücretlendirme ve Кати Hastanelerinde Uygulanan Performansa Dayall Ek Ödeme Sistemine Yönelik Hekim Tutumlarına İlişkin Bir Araştırma. Doktora Tezi. İstanbul Üniversitesi Sosyal Bilimler Enstitüsü. İstanbul.

Dwight, R. (1999). Searching for Real Maintenance Performance Measures. Journal of Quality of Maintenance Engineering. 5(3). 258275.

Ertekin, A. (2012). Кати Hastanelerinde Performansa Dayalı Ücret Ödemesi ve Çeşitli Meslek Grupları Açısından Değerlendirmesi (İzmir Dr. Suat Seren Göğüs Hastalıklarl ve Cerrahisi Eğitim ve Araştırma Hastanesi Örneği). Yüksek Lisans Tezi. Beykent Üniversitesi Sosyal Bilimler Enstitüsü. İstanbul.

Gazi, A. (2006). Sa Hastanelerinde Performansa Dayall Ek Ücret Ödeme Sisteminin Hastalar ve Sağllk Personeline Olan Etkisinin Analizi. Yüksek Lisans Tezi. Gazi Üniversitesi Sosyal Bilimler Enstitüsü. Ankara.

Gneezy, U. ve Rustichini, A. (2000). Pay Enough or Don't Pay At All. The Quarterly Journal of Economics. 63(4). 597.626.

Göksel, A. (2013). Işsletmelerde Performans Değerleme Sistemi Tasarımı (2.Baskı). Ankara: Nobel Yayıncilık.

Güngör, D. (2016). Psikolojide Ölçme Araçlarının Geliștirilmesi ve Uyarlanması Kılavuzu. Türk Psikoloji Yazıları. 19(38). 104112.

Harlow, H. F., Harlow, M. K. ve Meyer, D. R. (1950). Learning Motivated By a Manipulation Drive. Journal of Experimental Psychology. 40. 228-234.

Kalay, F. (2016). İşletmelerde Örgütsel Adaletin İşgören Performansı Üzerindeki Etkisi: Teorik Bir İnceleme. Kastamonu Üniversitesi İktisadi ve İdari Bilimler Fakültesi Dergisi. 11(1). 147158.

Keleş, H. N. (2006). İş Tatminin Örgütsel Bağlllık Üzerindeki Etkisine İlişkin İlaç Üretim ve Dağıtım Firmalarında Yapılan Bir Araştırma. Doktora Tezi. Selçuk Üniversitesi Sosyal Bilimler Enstitüsü, Konya. 
Geliştirme Çalışması

Kesici, B. (2005). Performansa Göre Ücretlendirme Sistemi Kahramanmaraş Devlet Hastanesi ile Kadın-Doğum ve Çocuk Hastanesinde Bir Araştırma. Yüksek Lisans Tezi. Kahramanmaraş Sütçü İmam Üniversitesi Sosyal Bilimler Enstitüsü. Kahramanmaraş.

Kılıç, G. (2012). Performansa Dayalı Ek Ödeme Sistemi. Yüksek Lisans Tezi. Dokuz Eylül Üniversitesi Sosyal Bilimler Enstitüsü. İzmir.

Kılıç, Ş. (2019). 360 Derece Performans Değerlendirme Sistemi Çerçevesinde Performansa Dayalı Ücretlendirmenin Türk Kamu Yönetiminde Uygulanabilirliği: Kırıkkale Belediyesi'nde Bir Araştırma. Yüksek Lisans Tezi. Kırıkkale Üniversitesi Sosyal Bilimler Enstitüsü. Kırıkkale.

Kohn, A. (1993). Punished By Rewards: The Trouble with Gold Stars. Incentive Plans, A's, Praise and Other Bribes. Boston: Houghton Mifflin.

Koca, M. (2019). Bankacllı Sektöründe Performansa Dayalı Prim Sisteminin Rolü Üzerine Bir Araştırma. Yüksek Lisans Tezi. Bilecik Şeyh Edebali Üniversitesi Sosyal Bilimler Enstitüsü. Bilecik.

Kolayl1, G. (2016). Performansa Dayalı Ek Ücret Sisteminin İkinci Basamak Sağllk Kurumlarında Çalışan Hekimlerin Motivasyon Algllarına Etkisi. Yüksek Lisans Tezi. Trakya Üniversitesi Sosyal Bilimler Enstitüsü. Edirne.

Kovan, Ö. (2020). Radyoloji Departmaninda Kullanilan Performansa Dayall Prim Uygulamalarının Çalışan Memnuniyeti Üzerine Etkisi: Özel Bir Sağllk Grubu Örneği. Yüksek Lisans Tezi. Acıbadem Mehmet Ali Aydınlar Üniversitesi Sağlık Bilimleri Enstitüsü. İstanbul.

Küçük, S. (2020). Performansa Dayalı Ücret Sistemleri ve Örgütsel Adalet ile Performansa Dayalı Ücret ile Adalet Algisl İlişkisini Belirlemeye Yönelik Bir Araștırma. Yüksek Lisans Tezi. İnönü Üniversitesi Sosyal Bilimler Enstitüsü. Malatya.

Lazear, E. P. (2000). Performance Pay and Productivity. The American Review Economics. 90 (5). 1346-1361.

Lee, G. (2011). Pay-for-Performance Pay System and Job Attitudes in Government Agencies. PhD. Thesis, University of Illionis. Chicago.
Lepper, M., Greene, D. ve Nisbett R. (1973). Underminig Children's Intrinsic Interest with Extrinsic Rewards: A Test of the Overjustification Hypothesis. Journal of Personality and Social Psychology. 28(1). 129137.

Marcotte, D. E. (2015). Performance Pay and the Impact on Teacher Motivation. PhD. Dissertation. Indiana State University Department of Educational Leadership. Indiana.

Marsh, J. S. (2014). Performance-Based Pay: Perceptions of Elementary Teachers of the Pandora School District. PhD. Thesis. University of Missouri. Kansas City.

Mellström, C. ve Johannesson, M. (2008). Crowding Out In Blood Donation- Was Titmuss Right? Journal of the European Economic Association. 6(4). 845-863.

Memiş, G. (2010). Performansa Dayalı Ücret Sisteminin Sağllk Hizmetlerine Etkisi ve Niğde Devlet Hastanesi'nde Görevli Sağllk Personeli Üzerinde Bir Araştırma. Yüksek Lisans Tezi. Niğde Üniversitesi Sosyal Bilimler Enstitüsü. Niğde.

Muogbo, U. S. (2013). The Influence of Motivation on Employees' Performance: A Study of Some Selected Firms in Anambra State. An International Journal of Arts and Humanities. 2(3). 134.151.

Murphy, K. R. ve Davidshofer, C. O. (2005). Psychological Testing. New Jersey: Prentice Hall.

Özdemir, S. (2019). Sağllk Bakanliğ Performansa Dayalı Ek Ücret Sisteminin Sağlık Çalışanları Tarafindan İs Verimliliği Açısından Değerlendirilmesi: Siirt Devlet Hastanesi Örneği. Yüksek Lisans Tezi. Toros Üniversitesi Sosyal Bilimler Enstitüsü. Mersin.

Öztunç, İ. (2017). Performansa Dayalı Ek Ödeme Sisteminin Kamu Sağllk Hizmetleri ve Sağllk Personeli Üzerine Etkisi: Zonguldak İli Kamu Hastaneleri Birliği Uygulaması. Yüksek Lisans Tezi. Bülent Ecevit Üniversitesi Sağlık Bilimleri Enstitüsü. Zonguldak.

Neely, A., Gregory, M., Platts, K. (1995). Performance Measurement System Design-A Literature Review and Research Agenda. International Journal of Operations \& Production Management. 15(4). 80-116. 
Peker, D. (2013). Performansa Dayall Ek Ödeme Yapılmasının Çalışan Motivasyonu Üzerindeki Etkileri (Çivril Devlet Hastanesi Örneği). Yüksek Lisans Tezi. Beykent Üniversitesi Sosyal Bilimler Enstitüsü, İstanbul.

Penley, L. ve Gould, S. (1988). Etzioni's Model of Organizational Involvement: A Perspective for Understanding Commitment to Organizations. Journal of Organizational Behavior. 9(1). 43-59.

Pink, D. (May 22. 2010). Forget Carrots and Sticks, They Don't Always Work. Telegraph. [http://www.telegraph.co.uk/finance/yourbusine ss/business-thinking/7752986/ Forget-carrotsand-sticks-they-dont-always-work.html].

(Erişim: 8 Mayıs 2020).

Pink, D. (2015). Drive-Nasıl Motive Oluruz? Nasıl Motive Ederiz? (Çeviren: Levent Göktem). İstanbul: Kapital Medya Hizmetleri.

Sabuncuoğlu, Z. (2013). İnsan Kaynaklart Yönetimi. İstanbul: Beta Basım Yayın Dağıtım.

Sağbaş, İ., Çalışkan, A., Hazman, G. G. ve Erin, M. Z. (2011). Yerel Yönetimlerde Performans Ölçümü: Teori ve Türkiye Uygulaması. Ankara: Seçkin Yayıncılık.

Seçer, İ. (2017). SPSS ve LISREL ile Pratik Veri Analizi Analiz ve Raporlaştırma. Ankara: Anı Yayıncilik.

Şendoğdu, A. (2014). Bankalarda Insan Kaynakları Yönetimi: İşe Alım Süreci ve Performans Değerlendirme. Ankara: Nobel Yayıncilik.

Taştan, S. (2017). Performansa Dayalı Ücret Sisteminin Sağllk Hizmetlerine Etkisi: Adiyaman İli Eğitim ve Araştırma Hastanesi Üzerine Bir Uygulama.Yüksek Lisans Tezi. Frrat Üniversitesi Sosyal Bilimler Enstitüsü. Elazığ.

Tezbaşaran, A. A. (2008). Likert Tipi Ölçek Hazırlama Kılavuzu. Mersin.

Timur, A. (2007). Hastane İsletmelerinde Maliyetleme Yaklaşımlarl ve Performansa Dayall Ücret Sistemi Bir Uygulama. Yüksek Lisans Tezi. Kocaeli Üniversitesi Sosyal Bilimler Enstitüsü. Kocaeli.

Uyargil, C., (2008). İşletmelerde Performans Yönetim Sistemi. İstanbul: Arıkan Basım-Yayın.
Uyargil, C., (2013). Performans Yönetimi Sistemi (3.Baskl). İstanbul: Beta Yayıncılık.

Uysal, Ş. (2015). Performans Yönetimi Sisteminin Tanımı, Tarihçesi, Amaç ve Temel Unsurlarına Genel Bir Bakış. Electronic Journal of Vocational Colleges. October/Ekim.2015. 32-39.

Uzuner, M. T. (2014). Performansa Dayalı Ücretlendirme Sistemleri ve Bilecik Ili Sağllk Bakanlı̆̆ Hastaneleri Uygulamaları.Yüksek Lisans Tezi. Gazi Üniversitesi Sosyal Bilimler Enstitüsü. Ankara.

Van Staveren, G. A. (2014). An Investigation in to Teacher Motivation and the Role of Merit Pay. PhD. Thesis. Oakland University. Michigan.

Venkatraman, N. ve Ramanujam, V. (1986). Measurement of Business Performance in Strategy Research: A Comparison of Approaches. Academy of Management Review. 11(4). 801.814.

Yüzden, G. E. (2013). Performansa Dayalı Ek Ödeme Sistemi ve Hekim Görüsslerinin Değerlendirilmesi. Yüksek Lisans Tezi. Gazi Üniversitesi Sosyal Bilimler Enstitüsü. Ankara. 
EK 1. Performansa Dayalı Ödeme Sisteminden Duyulan Memnuniyet Ölçeği (PEDÖS)

Aşağıda performansa dayalı ödeme konusunda bir dizi önerme yer almaktadır. Lütfen her bir önermeyi okuyarak bu görüşlere ne derece katılıp-katılmadığınızı işaretleyiniz.

1. Kesinlikle Katılmıyorum

2. Katılmiyorum

3. Kararsızım

4. Katiliyorum

5. Kesinlikle Katıliyorum

\begin{tabular}{|c|c|c|c|c|c|c|}
\hline No & Madde & 1 & 2 & 3 & 4 & 5 \\
\hline 1 & Performansa dayalı ödeme sisteminden memnunum. & & & & & \\
\hline 2 & $\begin{array}{l}\text { Performansa dayalı ödeme sisteminin çalışanlar için faydalı olduğunu } \\
\text { düşünüyorum. }\end{array}$ & & & & & \\
\hline 3 & Performansa dayalı ödeme sistemi performansımı artırmaktadır. & & & & & \\
\hline 4 & Performansa dayalı ödeme sistemi sayesinde gelirim artmaktadır. & & & & & \\
\hline 5 & Performansa dayalı ödeme sistemi verdiğim hizmetin kalitesini artırmaktadır. & & & & & \\
\hline 6 & $\begin{array}{l}\text { Performansa dayalı ödeme sisteminde başarılı çalışanlar } \\
\text { ödüllendirilmektedir. }\end{array}$ & & & & & \\
\hline 7 & $\begin{array}{l}\text { Çalıştığım kurumda uygulanan performansa dayalı ödeme sisteminin adil } \\
\text { olduğunu düșünüyorum. }\end{array}$ & & & & & \\
\hline 8 & $\begin{array}{l}\text { Diğer kurumlarla karşılaştırdığımda, çalıştığım kurumda uygulanan } \\
\text { performansa dayalı ödeme sisteminin adil olduğunu düșünüyorum. }\end{array}$ & & & & & \\
\hline 9 & $\begin{array}{l}\text { Performansa dayalı ödeme sistemi iş yükümü artırsa da, karşılığını aldığım } \\
\text { iccin mutsuz değilim. }\end{array}$ & & & & & \\
\hline 10 & $\begin{array}{l}\text { Performansa dayalı ödeme sistemi sayesinde, performansımdaki } \\
\text { değișiklikleri izleyebiliyorum. }\end{array}$ & & & & & \\
\hline 11 & $\begin{array}{l}\text { Performansa dayalı ödeme sistemi ile performansıma ilişkin geri bildirim } \\
\text { alabiliyorum. }\end{array}$ & & & & & \\
\hline 12 & $\begin{array}{l}\text { Performansa dayalı ödeme sistemi sayesinde bir para ödülü alma ihtimali } \\
\text { beni motive ediyor. }\end{array}$ & & & & & \\
\hline 13 & $\begin{array}{l}\text { Performansa dayalı ödeme sisteminin kurumların hizmet kalitesini } \\
\text { yükselttiğini düsünüyorum. }\end{array}$ & & & & & \\
\hline 14 & $\begin{array}{l}\text { Performansa dayalı ödeme sistemi mesleki yeterliliğimi artırmam için beni } \\
\text { motive etmektedir. }\end{array}$ & & & & & \\
\hline 15 & Performansa dayalı ödeme sistemi stres seviyemi yükseltmektedir. & & & & & \\
\hline 16 & $\begin{array}{l}\text { Performansa dayalı ödeme sistemi çalışanlar arasında aşırı rekabete yol } \\
\text { açmaktadır. }\end{array}$ & & & & & \\
\hline 17 & $\begin{array}{l}\text { Performansa dayalı ödeme sistemi, çalışanlar arasında huzursuzluk } \\
\text { yaratmaktadır. }\end{array}$ & & & & & \\
\hline 18 & $\begin{array}{l}\text { Performansa dayalı ödeme sisteminin suistimale açık olduğunu } \\
\text { düşünüyorum. }\end{array}$ & & & & & \\
\hline 19 & $\begin{array}{l}\text { Performansa dayalı ödeme sistemi uygulanırken çalışanlar arasında } \\
\text { ayrımcılık yapılmaktadır. }\end{array}$ & & & & & \\
\hline 20 & $\begin{array}{l}\text { Performansa dayalı ödeme sisteminin yarattığı baskı, çalışanların } \\
\text { performansını düşürmektedir. }\end{array}$ & & & & & \\
\hline 21 & $\begin{array}{l}\text { Performansa dayalı ödeme sistemi aracılığıyla elde ettiğim gelirin hak } \\
\text { ettiğimden az olduğunu düșünüyorum. }\end{array}$ & & & & & \\
\hline
\end{tabular}


